\title{
Brexit, Arbitration and Private International Law
}

\author{
Ahmed Al-Nuemat ${ }^{1} \&$ Abdullah Nawafleh ${ }^{2}$ \\ ${ }^{1}$ AL Balqa Applied University, Al-Salt, Jordan \\ ${ }^{2}$ University of Derby, England, United Kingdom \\ Correspondence: Ahmed Al-Nuemat, AL Balqa Applied University, Al-Salt, Jordan. E-mail: \\ ahmed_alnuemat@yahoo.com
}

Received: September 4, 2017

Accepted: September 29, 2017 Online Published: November 29, 2017

doi:10.5539/jpl.v10n5p116

URL: https://doi.org/10.5539/jpl.v10n5p116

\begin{abstract}
The United Kingdom voted to leave the European Union, ending a 40-year relationship. Britain's exit (Brexit) will no doubt affect European Union private international law, which is currently part of the United Kingdom's legal system. This article attempts to predict the sort of arbitration and private international law that the United Kingdom will have after its departure from the European Union. The article proposes that European Union private international law could be easily transposed into United Kingdom domestic law. In addition, the United Kingdom enforcement of court decisions in the European Union, after exiting the union and without concluding any further agreement with the union as to how jurisdiction must be allocated, should be achieved through the United Kingdom joining the Hague Convention on Choice of Court Agreements. Finally, the paper concludes that Brexit will increase the use of English law and the specification of England and Wales as the jurisdictions in international commercial contracts because the United Kingdom would no longer be required to incorporate those aspects of European law that can prove problematic.
\end{abstract}

Keywords: allocation of jurisdiction, applicable law, arbitration, Brexit, choice of law, contract terms, European Union law, enforcement, jurisdiction, recognition of judgments

\section{Introduction}

European Union law in the civil justice area has changed enormously since the creation of the union. The interpretation of European Union law by the Court of Justice and the complexity of the civil justice field of law have led to an increase in the number of Court of Justice judgments in this area (Inga, Baiba, Arnis, Mārtinšs, \& Aleksandrs, 2015). The Member States of the European Union have been faced with complex issues in this area of law: their national courts, institutions, and legal practitioners encounter the challenges of constant change in this area (Inga et al., 2015). Further, for the United Kingdom's legal system, since the creation of the European Court of Justice, evidence shows that the court has favoured civil law approaches over certain common law instruments (such as anti-suit injunctions), which have been significantly diminished (Inga et al., 2015).

The British people voted for the United Kingdom's withdrawal from the European Union in the June 2016 referendum. On $2^{\text {nd }}$ October 2016, the United Kingdom's Prime Minister, Theresa May, stated that a Great Repeal Bill to repeal the 1972 European Communities Act and European Union regulations would be transposed into domestic law, wherever practical, with effect from the date of British withdrawal (BBC News, 2 October 2016). (Note 1) The repeal bill would enable Parliament to amend or cancel on a case-by-case basis any unwanted legislation and also end the jurisdiction of the European Court of Justice in the United Kingdom (BBC News, 2 October 2016). However, in R (Miller) v Secretary of State for Exiting the European Union, the High Court held that 'the Secretary of State does not have the power under the Crown's prerogative to give notice pursuant to Article 50 of the Treaty on the European Union for the United Kingdom to withdraw from the European Union.' ("R (Miller) -v- Secretary of State for Exiting the European Union,") This means that Parliament had made European Union law part of United Kingdom law, which could be undone only by the action of Parliament, under the principle of Parliamentary sovereignty. However, on $29^{\text {th }}$ March 2017, the United Kingdom officially triggered Article 50 with a letter informing the European Council of Britain's intention to leave the European Union ("Correspondence - Prime Minister's letter to Donald Tusk triggering Article 50," 29/03/2017).

According to Article 50(2) of the Treaty on the European Union, once a Member State has notified the European 
Council of its intention to leave the European Union, the European Union and the withdrawing state must conclude a 'withdrawal agreement'. Article 50(3) stipulates that 'the treaties shall cease to apply to the state in question from the date of entry into force of the withdrawal agreement, or failing that, two years after the notification... unless the European Council, in agreement with the Member State concerned, unanimously decides to extend this period.' Thus, if there is no withdrawal agreement and no extension of the two-year period, Article 50(3) will have an effect and the treaties will cease to apply. However, Article 288 of the Treaty on the Functioning of the European Union states that a 'regulation shall have general application. It shall be binding in its entirety and directly applicable to all Member States.' Thus, when the treaty ceased, the European Union regulations were no longer applicable in the United Kingdom.

In addition, Section 2(1) of the European Communities Act 1972 provides that 'All such rights, powers, liabilities, obligations and restrictions from time to time created or arising by or under the treaties'(The United Kingdom Parliament, 24 December 2010), including all remedies and procedures provided under the treaties, and in accordance with the treaties, are without further enactment to be given legal effect or used in the United Kingdom; shall be recognised and available in law; and shall be enforced, allowed, and followed accordingly. Thus, the treaties (the Treaty on the European Union and the Treaty on the Functioning of the European Union) ceased when Article 50 was triggered by the United Kingdom, and Section 2(1) no longer has any legal effect in the country (Basedow, 2016). (Note 2) This will impact fundamental European Union private international law in the United Kingdom, particularly the Brussels I and II Regulations, the Rome I and Rome II Regulations, the Maintenance Regulation, the Evidence and Service Regulations, and the Insolvency Regulations (Dickinson, 2016). (Note 3) The following sections will discuss the situation for jurisdiction and judgments in civil and commercial matters and the law applicable to contractual and non-contractual obligations, as well as the best options for the United Kingdom in this field of law after Brexit.

\section{Jurisdiction and Judgments in Civil and Commercial Matters}

Before discussing the United Kingdom's best options regarding jurisdiction and the enforcement of court decisions after Brexit, it is important to describe the current situation regarding the European rules assigning jurisdiction for the dispute, recognition, and enforcement of judgments in civil and commercial matters. In 1968, the European Economic Community Member States concluded the Brussels Convention, which applies only to civil and commercial matters, including rules on the jurisdiction of national courts and rules on foreign judgment recognition and enforcement (Giardina, 1978). The United Kingdom did not join this convention until 1987 (High Court Enforcement Group Limited, 2016). However, the rules regarding judgment enforcement were set under Regulation (EU) 1215/2012 (Brussels I Recast) (The European Parliament and the Council of the European Union, 2012), and the Civil Procedures Rules, which allows the courts in European Union Member States to treat judgments awarded in other European Union countries as if they had been awarded in their jurisdictions (High Court Enforcement Group Limited, 2016).

The Lugano Convention 2007 set the rules of the jurisdiction, recognition, and enforcement of judgments between European Union Member States and Switzerland, Norway, and Iceland (EFTA states but not Lichtenstein). This convention was concluded by the European Commission on behalf of all European Union Member States. Further, the Convention allows non-European Union Member States to accede to the new convention under certain conditions ("Strengthening cooperation with Switzerland, Norway and Iceland: the Lugano Convention (2007)," 2014).

The Lugano Convention 2007 is different from the Brussels I Regulation: Council Regulation (EC) 44/2001. The difference exists in the role of the Court of Justice of the European Union, which has the right to interpret the Brussels I Regulation, even for Denmark, which was a late adherent to Brussels I. Although the Brussels I Regulation is not directly applicable to Denmark, it has effectively been extended to Denmark by a separate agreement between the European Union and Denmark, which took effect on $1^{\text {st }}$ July 2007. (Note 4) In addition, the Brussels I Regulation also applies to new European Union Member States (The European Parliament and the Council of the European Union, 2012).

The preamble of Lugano Convention 2007 Protocol 2 on the uniform interpretation of the convention and on the Standing Committee identifies the danger of 'divergent interpretations' of Regulation (EC) No 44/2001 and the Lugano Convention 2007 (Ghai et al., 1987). However, the Court of Justice of the European Union does not have jurisdiction over the courts of Switzerland, Norway, and Iceland on issues of interpretation of the Lugano Convention 2007, although it does for all European Union Member States (Jacobs, 2014).

However, Article 1(1) of Protocol 2 of the Lugano Convention 2007 requires that any EFTA state court applying and interpreting this convention must pay due account to the principles laid down by any relevant provisions of 
the Lugano Convention 1988. In addition, it must consider the instruments referred to in the Brussels I Regulation (EC) No. 44/2001, as well as any amendments to this regulation. Also, it must consider the Brussels Convention 1968, and the protocol on interpretation of this convention by the Court of Justice of the European Communities, signed in Luxembourg on 3 June 1971, as amended by the conventions of accession to the said convention and the said protocol by the states acceding to the European Community. Moreover, it must consider the interpretation of the agreement between the European Community and Denmark on jurisdiction and the recognition and enforcement of judgments in civil and commercial matters, signed in Brussels on 19 October 2005. The Lugano Convention had a direct effect in the United Kingdom under the European Communities Act 1972, as the Council Decision 2007/712 /EC of 15 October 2007 made the convention a European Union Act (Ghai et al., 1987).

From the above, it appears that the best solution for the United Kingdom in relation to the enforcement of court decisions in the European Union, after exiting the union and without concluding any further agreement as to how jurisdiction must be allocated, should be through joining the Hague Convention on Choice of Court Agreements.

The European Union is a signatory to the Hague Convention on Choice of Court Agreements on behalf of Member States. In June 2005, the Hague Conference on Private International Law concluded the Convention on Choice of Court Agreements. On $1^{\text {st }}$ October 2015, the convention became binding on European Union Member States (excluding Denmark). The convention scope is similar to the Brussels I Regulation (Recast). However, the convention is only applicable to the exclusive choice of court agreements - the recognition and enforcement of judgments by competent courts that have jurisdiction under the convention.

The suggestion that the United Kingdom's best interest is to join the Hague Convention on Choice of Court Agreements is based on two advantages. First, the convention gives the same effect as the Brussels Regulations (Recast) in relation to the exclusive choice of court agreements. The second advantage is that the Hague Convention requires that the courts of contracting states must suspend or dismiss proceedings issued where there is an exclusive choice of another court. Thus, in regard to agreed exclusive jurisdiction clauses for parties, the Hague Convention mirrors the terms of the Brussels Regulations (Recast). Therefore, this will give the United Kingdom the chance to stop the revival of the so-called 'Italian torpedo'(Note 5) following Brexit (Kenny \& Hennigan, 2015).

\section{Potential Opportunities for International Arbitration in the United Kingdom}

For the United Kingdom, Brexit could ease the European Court of Justice's restrictions on anti-suit injunctions. This mechanism has been used frequently in United Kingdom courts as an order against a private party with the aim of either preventing that party raising an action in another forum or obliging that party to cease such an action if already started (Dowers, 2013). A party that ignores the anti-suit injunction will face sanctions in the enjoining forum (Dowers, 2013). This shows the power of the anti-suit injunction as a mechanism for preventing duplicative litigation, especially if the party has a business interest or owns property in the issuing forum (Dowers, 2013). Generally, the European Court of Justice has favoured civil law approaches over common law, highlighting the practical relevance of certain common law instruments, such as anti-suit injunctions (Inga et al., 2015).

The European Court of Justice has considered anti-suit injunctions incompatible with the Brussels Regulation. In Case C-185/07 Allianz (formerly Riunione Adriatica di Sicurta Spa) and Others v West Tankers Inc., the court endorsed the opinion of its advocate general that anti-suit injunctions are incompatible with the regulation, discounting a number of arguments put forward to the court by the House of Lords and the United Kingdom government and reflected this in much of the commentary on the opinion ("Allianz SpA and Generali Assicurazioni Generali SpA v West Tankers Inc.," 2009) (Peter, Ian, \& Vanessa, 2009). While the judgment of the European Court of Justice does not recognise anti-suit injunctions seeking to restrain proceedings in European Union Member States, courts in the European Union have the right to grant such injunctions against courts outside the European Union, with the purpose of restraining the bringing or continuing of proceedings in breach of an arbitration agreement("Allianz SpA and Generali Assicurazioni Generali SpA v West Tankers Inc.," 2009) (Peter et al., 2009). The power of using anti-suit injunctions after Brexit will make the United Kingdom more competitive in relation to international arbitration centres such as New York, Bermuda, and Singapore. In addition, after Brexit, the English courts will not be bound by the European Court of Justice's case law and will not be bound to sanction an arbitration award that is contrary to European Union law. Further, European Union public policy will no longer form part of English public policy for the purposes of Article V(l)(c) and (e) and (11)(b) of the New York Convention ("Eco Swiss China Time Ltd v Benetton International NV," 1999).

The Arbitration Act of 1996 stipulates a solid and sufficient foundation for London-based arbitration (Alex et al., 
11/1/2017). In particular, Section 46 of the Arbitration Act 1996 will be unaltered to the degree that tribunals have to fall back to the national law of England. Tribunals are used to adjudge a dispute according to the chosen applicable enactment, as Section 46(1) of the Arbitration Act 1996 stipulates. In that regard, it is adequate to infer that the English Arbitration Act 1996 gives the arbitration parties considerable self-governance in the practice of their conflict resolution and discourages juridical intervention during arbitration activities, unless where it is stringently imperative to intervene in the arbitration process for the function of support (Alex et al., 11/1/2017).

The United Kingdom has a dominant place in international arbitration (Wales), particularly the city of London, which is often chosen as a neutral seat of arbitration for major international disputes involving parties of different nationalities (Kryvoi \& Yokomizo, 2016). (Note 6) London is also well-known for its specialist and experienced arbitrators. Even after Brexit, according to TheCityUK, London has been the seat or centre for the majority of international commercial arbitrations, mediations, and adjudications (Andrew, Vanessa, \& Hannah, 2016). Furthermore, in 2010, Queen Mary University of London (QMUL) conducted a survey called the 2010 International Arbitration Survey, which collected perceptions from 136 firms. (Note 7) The survey found that $40 \%$ of the respondents preferred the application of English law in arbitrations, while 17\% opted for New York state law. The survey also found that $30 \%$ of the respondents preferred London-based legal jurisdiction, while $9 \%$ preferred a Geneva-based seat of arbitration. The major reason behind the preferences was the formal legal framework within the particular jurisdiction. This was pointed out by $62 \%$ of the respondents. This formal legal framework encompassed English national arbitration law, the historical performance in enforcing arbitration agreements and awards, non-partisanship, and impartiality. The second major reason was the law applicable to the particular dispute, as cited by $46 \%$ of the respondents, followed by convenience (third major factor), as cited by $45 \%$. Other factors included physical location, language, the cultures of the parties involved, and the efficiency of tribunal proceedings (Mistelis \& Martin, 2010).

The United Kingdom and European Union Member States are parties to the 1958 New York Convention on the Recognition and Enforcement of Foreign Arbitral Awards, and their obligations under the convention are entirely independent of European Union membership and are not affected by states exiting the European Union. The New York Convention requires courts of contracting states to agree that foreign and non-domestic arbitral awards will not be discriminated against. Further, contracting states are obliged to ensure such awards are recognised and generally capable of enforcement in their jurisdictions in the same way as domestic awards are (United Nations). (Note 8) Therefore, following Brexit, an agreement to arbitrate in the United Kingdom and a resulting award continue to be enforceable across the European Union. Commentators have suggested that Brexit will not affect London's popularity as a seat for international arbitration and will not affect businesses' choice of this city (Wahab, 2016).

It is true that the dispute resolution provisions in contract clauses are important for any future businesses. These provisions ensure that any future dispute will be placed in the hands of a competent and effective court or tribunal. Some have argued that uncertainty in the Brexit process has made businesspeople have little idea as to what will replace the European Union regulations (See for example Druces LLP, 2016). The issue of judgment enforcement after Brexit will no doubt affect not only the United Kingdom as a country but also European Union states wishing to enforce judgments in the United Kingdom. These European Union states will find enforce judgments in the United Kingdom costlier and slower (High Court Enforcement Group Limited, 2016). The United Kingdom's decision to leave the European Union has inevitably created some uncertainty, which may increase the attractiveness of arbitration, the enforcement mechanism for which is unaffected.

\section{The Law Applicable to Contractual and Non-Contractual Obligations}

The United Kingdom Ministry of Justice's reports on legal services have highlighted the popularity of English law and the English courts in cross-border international transactions, particularly their quality, certainty, stability, clarity, and predictably (Ministry of Justice, 2013). In addition, English law is often described as one of the most precise and detailed contract laws in the world (Cuniberti). Further, the choice of the law governing contracts significantly affects the external dispute resolution rate, whereby several studies have ranked English law as the first law chosen (See for example Singapore Academy of Law, 2016); (Cuniberti). The United Kingdom system recognises and respects freedom of contract. This has been reflected in the recent case Arnold v Britton, judged by the United Kingdom Supreme Court, which indicated that the function of the court is not to rewrite a commercial bargain between parties ("Arnold v Britton and others," 10 June 2015).

For European Union Member States, the Rome I and Rome II Regulations for the purposes of civil and commercial matters determine the governing law for contractual and non-contractual obligations, respectively. 
The main principle of Rome I is to provide parties with the freedom to choose the law governing their contract. The law chosen by the parties might be the law of the country, which both parties not domicile. The courts of European Union Member States continue to apply the Rome I Regulation (EC/593/2008), which gives effect to non-European Union law, in the same way as a European Union Member State's law. Therefore, the Rome I and Rome II Regulations respect parties' choice of law, regardless of whether they select the law of the European Union or that of a non-European Union country. Thus, after Brexit, the courts of European Union Member States should continue to respect a choice of English law.

For the United Kingdom, the Rome I and Rome II Regulations will cease to have an effect. However, the United Kingdom Contracts Applicable Law Act 1990 already broadly reflects the provisions of Rome I. Whatever the legal instrument that will be agreed upon after Brexit, the principles set out in the Rome I and Rome II Regulations will continue to apply in the United Kingdom. In addition, the United Kingdom government should not damage the popularity of English law as the choice of law by adopting a different regime after Brexit. Thus, the new United Kingdom regulation regime should reflect Rome I and II and avoid going back to the issues that were not covered by English law before joining Rome I and II. For instance, English law did not recognise an expressed choice of law to govern non-contractual disputes before joining Rome II (Stuart \& Daniel, 2016). Brexit will not stop parties to international commercial transactions around the world from picking English law to govern their commercial contracts. As shown above, English law is often chosen due to reasons unconnected with the United Kingdom's present membership of the European Union, including its predictability and commerciality.

\section{Conclusion}

The exit of the United Kingdom from the European Union, no doubt has caused uncertainty in world politics and the economy, but certainty the English legal system will continue to be of international importance. The history of the United Kingdom shows that its disputes tribunals were designed with international perspective. English Common Law is the most widespread legal system in many countries around the world (the United States, Canada, Australia, New Zealand, India, Pakistan, Republic of Ireland, and the rest of the nations in Common Law countries). The question of how the private international law relationship between the United Kingdom and the European Union should be shaped remains one of the issues that the United Kingdom government needs to address in future negotiations after trigging Article 50 of the Treaty on the European Union. European Union private international law (the common regime established by the Brussels and Rome Regulations) has shaped English law in many ways, and the United Kingdom government needs to decide to what extent European Union legislation should effectively remain in place. However, the best interest of the United Kingdom government is to continue using the most practical European Union regulations, which have already transplanted to or are part of the United Kingdom legal system, not least because of the sheer volume of new domestic laws that would otherwise be required after Brexit. In terms of jurisdictions and the enforcement of jurisdictions and judgments in civil and commercial matters, the best and easiest way for the European Union to recognise the United Kingdom rules for assigning jurisdictions for dispute and for the recognition and enforcement of judgments in civil and commercial matters would be for the United Kingdom to join the Hague Convention on Choice of Court Agreements, as the Hague Convention reflects the terms of the Brussels Regulations (Recast). Regarding the matter of the law applicable to contractual and non-contractual obligations, United Kingdom law, particularly English law, dominates as the chosen law for international transactions. In addition, English contract law is largely unaffected by European Union law. Studies have shown that English law provides a sound platform for drafting contracts for international business, which expressly regulates how the parties will deal with future changes. Therefore, English law should be capable of dealing with the changes caused by Brexit for contracting parties.

In regard to the enforcement of arbitration awards, the United Kingdom and European Union Member States are parties to the 1958 New York Convention, and their obligations under the convention are entirely independent of European Union membership and are not affected by states exiting the European Union. Further, Brexit will not affect London's popularity as a seat for international arbitration, due to the reputation of the United Kingdom judiciary, the Arbitration Act, and the legal infrastructure, not because of its membership of the European Union. It remains to be seen which route the United Kingdom will follow in its exit negotiations regarding the issues of the private international law relationship with the European Union.

\section{References}

Aikens, R., \& Dinsmore, A. (2016). Jurisdiction, Enforcement and the Conflict of Laws in Cross-Border Commercial Disputes: What Are the Legal Consequences of Brexit? European Business Law Review, 27(7), 903-920. 
Alex, G., David, J., Stephen, M., Simon, N., Thomas, R., Samar, A., . . Angeline, W. (11/1/2017). Commercial Bar Association Brexit Report Arbitration Sub-Group.

Allianz SpA and Generali Assicurazioni Generali SpA v West Tankers Inc., Case C-185/07 (2009).

Andrew, C., Vanessa, N., \& Hannah, A. (2016). Anti-Suit Injunctions and Arbitration Post-Brexit. Retrieved from https://www.herbertsmithfreehills.com/latest-thinking/anti-suit-injunctions-and-arbitration-post-brexit

Arnold v Britton and others, [2015] UKSC 36 (The Supreme Court 10 June 2015).

Basedow, J. (2016). Brexit, Private Law and Commercial Law. Zeitschrift für Europäisches Privatrecht (3).

BBC News. (2 October 2016). Brexit: Theresa May to trigger Article 50 by end of March. Retrieved from http://www.bbc.com/news/uk-politics-37532364

Consolidated Version Of The Treaty On European Union, C 115/13 C.F.R. (2008).

Correspondence - Prime Minister's letter to Donald Tusk triggering Article 50. (29/03/2017). Retrieved from https://www.gov.uk/government/uploads/system/uploads/attachment_data/file/604079/Prime_Ministers_lett er_to_European_Council_President_Donald_Tusk.pdf

Cuniberti, G. (2014). The International Market for Contracts: The Most Attractive Contract Laws. Northwestern $J$ Intl L \& Bus, 23, 455, 472-473.

Dickinson, A. (2016). Back to the Future-The UK's EU Exit and the Conflict of Laws. Journal of Private International Law, 12(2), 195-210. https://doi.org/10.1080/17441048.2016.1209847

Dowers, N. A. (2013). Anti-Suit Injunction and the EU: Legal Tradition and Europeanisation in International Private Law, The. Cambridge J. Int'l \& Comp. L., 2, 960. https://doi.org/10.7574/cjicl.02.04.138

Druces LLP. (2016). Dispute resolution provisions: the impact of Brexit. The In-House Lawyer, 104-105.

Eco Swiss China Time Ltd v Benetton International NV, Case C-126/97 (1999).

Ghai, Y., Luckman, R., Francis, S., Ghai, Y., Luckman, R., \& Francis, S. (1987). The Political Economy of Law: a Third World Reader: Delhi: Oxford University Press.

Giardina, A. (1978). The European Court and the Brussels Convention on Jurisdiction and Judgments. International and Comparative Law Quarterly, 27(02), 263-276. https://doi.org/10.1093/iclqaj/27.2.263

Hess, B. (2016). Brexit and European international private and procedural law. Retrieved from https://www.mpg.de/10824865/back-to-the-past

High Court Enforcement Group Limited. (2016). Brexit,judgment, HCEO, European Enforcement Order, Brussels Regulation, Lugano Convention, bilateral | HCE Group.

Inga, K., Baiba, R., Arnis, B., Mārtinšs, D., \& Aleksandrs, F. (2015). The Court of Justice of the European Union and the impact of its case law in the area of civil justice on national judicial and administrative authorities (Latvia, Hungary, Germany, Sweden and the United Kingdom): The Law Office of Inga Kacevska and the Ministry of Justice of the Republic of Latvia, Project "The Court of Justice of the European Union and its case law in the area of civil justice" JUST/2013/JCIV/AG/4691 (No. TM 2014/13/EK).

Jacobs, F. G. (2014). Member States Of The European Union Before The International Court Of Justice. In I. Govaere, E. Lannon, P. V. Elsuwege, S. Adam, \& M. Maresceau (Eds.), The European Union in the world : essays in honour of professor Marc Maresceau. Leiden: Martinus Nijhoff Publishers

Kenny, D., \& Hennigan, R. (2015). Choice-of-Court Agreements, the Italian Torpedo, and the Recast of the Brussels I Regulation. International and Comparative Law Quarterly, 64(01), 197-209. https://doi.org/10.1017/S0020589314000621

Kryvoi, Y., \& Yokomizo, D. (2016). Improving Arbitration Climate in Japan: Report and Recommendations. Retrieved from https://ssrn.com/abstract=2865717

Lein, E. (2016). Unchartered territory? A few thoughts on private international law post Brexit. Yearbook of Private International Law, 17, 33-47. https://doi.org/10.9785/9783504385163-004

Masters, S., \& McRae, B. (2016). What Does Brexit Mean for the Brussels Regime? Journal of International Arbitration, 33(7), 483-499.

Ministry of Justice. (2013). UK Legal Services on the International Stage: Underpinning growth and stability. Retrieved from https://www.gov.uk/government/uploads/system/uploads/attachment_data/file/219802/ legal-services-action-plan-0313.pdf 
Mistelis, L., \& Martin, P. (2010). International Arbitration Survey: Choices in International Arbitration: London, Queen Mary School of Law, School of International Arbitration.

Peter, M., Ian, M., \& Vanessa, E. (2009). European Court of Justice Rules That Anti-suit Injunctions are Contrary to EU Law. from http://www.klgates.com/european-court-of-justice-rules-that-anti-suit-injunctions-are-contrary-to-eu-law-02 $-10-2009 /$

R (Miller) -v- Secretary of State for Exiting the European Union, Case No. CO/3809/2016 and CO/3281/2016 (High Court of Justice.

Singapore Academy of Law. (2016). Study on Governing Law \& Jurisdictional Choices in Cross-border Transac tions: BlackBox Research Pte Ltd.

Strengthening cooperation with Switzerland, Norway and Iceland: the Lugano Convention. (2007). Retrieved from http://eur-lex.europa.eu/legal-content/EN/TXT/?uri=URISERV\%3Al16029

Stuart, P., \& Daniel, H. (2016). Selection Of English Governing Law, Jurisdiction Post-Brexit. Law360. Retrieved from www.law360.com

Regulation (EU) No 1215/2012 of the European Parliament and of the Council of 12 December 2012 on Jurisdiction and the Recognition and Enforcement of Judgments in Civil and Commercial Matters (recast), (2012).

The United Kingdom Parliament. (24 December 2010). The EU Bill and Parliamentary Sovereignty - European Scrutiny Committee Contents Retrieved from http://www.publications.parliament.uk/pa/cm201011/cmselect/cmeuleg/633/63304.htm

Convention on the Recognition and Enforcement of Foreign Arbitral Awards (New York, 1958).

Wahab, M. S. A. (2016). Brexit's Chilling Effect on Choice of Law and Arbitration in the United Kingdom: Practical Reflections Between Aggravation and Alleviation. Journal of International Arbitration, 33(4), 463-481.

Wales, T. L. S. o. E. a. England and Wales: The jurisdiction of choice. Retrieved from http://www.eversheds.com/documents/LawSocietyEnglandAndWalesJurisdictionOfChoice.pdf

\section{Notes}

Note 1. The 1972 European Communities Act is the crucial piece of legislation that makes European Union law automatically binding in the United Kingdom. If there is a clash with British law, European Union law takes precedence.

Note 2. For the United Kingdom, the partnership with the European Union ceased after its withdrawal from the union, but what is the situation with regard to conventions that were ratified by the European Union on behalf of all Member States but not by the states themselves? It is obvious that the case for conventions that have been ratified by the United Kingdom and the European Union will continue to apply, for instance the Montreal Convention for the Unification of Certain Rules for International Carriage by Air or the Cape Town Convention on International Interests in Mobile Equipment and the Aviation Protocol, which the United Kingdom and the European Union have ratified separately.

Note 3. See also (Aikens \& Dinsmore, 2016; Dickinson, 2016; Hess, 2016; Lein, 2016; Masters \& McRae, 2016)

Note 4. The Brussels I Regulation (Recast) was implemented by Denmark by Danish Law No. 518 of $18^{\text {th }}$ May 2013 (containing amendments to the act on the 2001 Brussels Regulation), which entered into force on $1^{\text {st }}$ June 2013.

Note 5. The 'Italian torpedo' involves the use of litigation with the primary purpose of delay. An action is filed in Italy, despite the existence of a valid agreement between the parties for the matter to be heard in another Member State. The Italian courts, not known for their speed, could take a long time to make a determination on jurisdiction. Any action filed in the appropriate courts - the courts that were agreed between the parties - must wait for the determination of the Italian courts that they have no jurisdiction before proceeding. The resulting delay can be of significant litigious advantage to one party and cause significant unfairness to the other. 
Note 6. The number of new cases registered yearly with the London Court of International Arbitration (LCIA) often exceeds 300, with the vast majority of disputes handled by London law firms and involving an international party.

Note 7. In consideration of arbitration, it is prudent to note the distinction between the governing statutes from the perspective of the substantive law applied during arbitration and the governing statutes of the arbitration. The governing statutes of the arbitration refer to the provisions for conducting arbitration in a specific jurisdiction.

Note 8. The New York Convention entered into force on $7^{\text {th }}$ June 1959 (Article XII).

\section{Copyrights}

Copyright for this article is retained by the author(s), with first publication rights granted to the journal.

This is an open-access article distributed under the terms and conditions of the Creative Commons Attribution license (http://creativecommons.org/licenses/by/4.0/). 